\title{
Efficient recombinant expression and secretion of a thermostable GH26 mannan endo-1,4- $\beta$-mannosidase from Bacillus licheniformis in Escherichia coli
}

\author{
Chomphunuch Songsiriritthigul+1 ${ }^{+1}$ Bancha Buranabanyat ${ }^{\dagger 2}$, Dietmar Haltrich ${ }^{3}$ and Montarop Yamabhai*2
}

\begin{abstract}
Background: Mannans are one of the key polymers in hemicellulose, a major component of lignocellulose. The Mannan endo-1,4- $\beta$-mannosidase or 1,4- $\beta$-D-mannanase (EC 3.2.1.78), commonly named $\beta$-mannanase, is an enzyme that can catalyze random hydrolysis of $\beta-1,4-$ mannosidic linkages in the main chain of mannans, glucomannans and galactomannans. The enzyme has found a number of applications in different industries, including food, feed, pharmaceutical, pulp/paper industries, as well as gas well stimulation and pretreatment of lignocellulosic biomass for the production of second generation biofuel. Bacillus licheniformis is a Gram-positive endospore-forming microorganism that is generally non-pathogenic and has been used extensively for large-scale industrial production of various enzymes; however, there has been no previous report on the cloning and expression of mannan endo-1,4- $\beta$ mannosidase gene (manB) from B. licheniformis.

Results: The mannan endo-1,4- $\beta$-mannosidase gene (manB), commonly known as $\beta$-mannanase, from Bacillus licheniformis strain DSM13 was cloned and overexpressed in Escherichia coli. The enzyme can be harvested from the cell lysate, periplasmic extract, or culture supernatant when using the pFLAG expression system. A total activity of approximately 50,000 units could be obtained from 1-I shake flask cultures. The recombinant enzyme was $6 \times$ Histagged at its C-terminus, and could be purified by one-step immobilized metal affinity chromatography (IMAC) to apparent homogeneity. The specific activity of the purified enzyme when using locust bean gum as substrate was $1672 \pm 96$ units $/ \mathrm{mg}$. The optimal pH of the enzyme was between pH 6.0 - 7.0; whereas the optimal temperature was at $50-60^{\circ} \mathrm{C}$. The recombinant $\beta$-mannanase was stable within $\mathrm{pH} 5-12$ after incubation for $30 \mathrm{~min}$ at $50^{\circ} \mathrm{C}$, and within pH 6 - 9 after incubation at $50^{\circ} \mathrm{C}$ for $24 \mathrm{~h}$. The enzyme was stable at temperatures up to $50^{\circ} \mathrm{C}$ with a half-life time of activity $(\tau 1 / 2)$ of approximately $80 \mathrm{~h}$ at $50^{\circ} \mathrm{C}$ and $\mathrm{pH}$ 6.0. Analysis of hydrolytic products by thin layer chromatography revealed that the main products from the bioconversion of locus bean gum and mannan were various manno-oligosaccharide products (M2 - M6) and mannose.
\end{abstract}

Conclusion: Our study demonstrates an efficient expression and secretion system for the production of a relatively thermo- and alkali-stable recombinant $\beta$-mannanase from $B$. licheniformis strain DSM13, suitable for various biotechnological applications.

\section{Background}

The Mannan endo-1,4- $\beta$-mannosidase or 1,4- $\beta$-D-mannanase (EC 3.2.1.78), commonly named $\beta$-mannanase, is

\footnotetext{
* Correspondence: montarop@sut.ac.th

2 School of Biotechnology, Institute of Agricultural Technology, Suranaree University of Technology, 111 University Avenue, Nakhon Ratchasima, Thailand + Contributed equally

Full list of author information is available at the end of the article
}

an enzyme that can catalyze random hydrolysis of $\beta-1,4-$ mannosidic linkages in the main chain of $\beta-1,4$-mannans, glucomannans and galactomannans; thus it transforms the abundant heteromannans to manno-oligosaccharides $[1,2]$ and a small amount of mannose, glucose and galactose [3]. Mannan endo-1,4- $\beta$-mannosidases are produced by a number of plants, bacteria, fungi, and by various 
invertebrates. The enzyme has found a number of applications in different sectors [4], including food, feed, pharmaceutical, and pulp/paper industries, gas well stimulation [1], as well as pre-treatment of lignocellulosic biomass for the production of second generation biofuel [2]. The application of mannan endo-1,4- $\beta$-mannosidase for the production of prebiotic manno-oligosaccharides from cheap agricultural by-products such as copra has recently gained significant interests [5-8].

Bacillus licheniformis is a Gram-positive endosporeforming microorganism that belongs to the $B$. subtilis group of the genus Bacillus. It is generally non-pathogenic and has been used extensively for large-scale industrial production of exoenzymes such as subtilisins or amylase, and the antibiotic bacitracin [9]. Recently, the genome of $B$. licheniformis strain DSM13 has been reported and it was revealed that it contains many new genes of potential interest for biotechnological applications [10]. So far, there has been no previous report on the cloning and expression of mannan endo-1,4- $\beta$-mannosidase gene $(\operatorname{man} B)$ from $B$. licheniformis; however, there were some preliminary reports on the property of native enzymes [11,12]. In this work $\operatorname{man} B$ from $B$. licheniformis strain DSM13, which has been used extensively in industry, was cloned and overexpressed using an Escherichia coli expression system [13]. The recombinant enzyme was highly expressed and efficiently secreted into the periplasmic space and subsequently into the culture medium. Amino acid sequence analysis revealed that the enzyme belongs to the glycosyl hydrolase family GH26 [14]. The properties of the recombinant enzyme are also reported, and our results demonstrate that recombinant mannan endo-1,4- $\beta$-mannosidase from $B$. licheniformis is thermo- and alkali-stable, and thus suitable for various industrial applications.

\section{Results \\ Cloning and expression of mannan endo-1,4- $\beta$ - mannosidase from Bacillus licheniformis}

The oligonucleotide primers for cloning of the $\operatorname{man} B$ gene encoding mannan endo-1,4- $\beta$-mannosidase from $B$. licheniformis DSM13 were designed from its complete genomic database, according to the DNA sequence of gene $y d h T$ (NCBI accession number NC006322), encoding a hypothetical protein similar to mannan endo-1,4beta-mannosidase. The gene was cloned into the pFLAG expression vector such that the hypothetical native signal peptide was replaced with the E. coli OmpA signal peptide included in this vector. This allows the secretion of the recombinant enzyme into the periplasmic space and subsequently into culture broth. In addition, the DNA sequence encoding a hexahistidine together with a stop codon was incorporated into the reverse primers to create a His-tagged fusion enzyme to facilitate further puri- fication. The $\operatorname{manB}$ gene was under control of the $t a c$ promoter and could be induced for high expression using Isopropyl $\beta$-D-1-thiogalactopyranoside (IPTG). Amino acid sequence analysis revealed that the mannan endo1,4- $\beta$-mannosidase from $B$. licheniformis has a theoretical molecular mass of $41 \mathrm{kDa}$, and belongs to glycosyl hydrolase family GH26, according to the CAZy (CArbohydrateActive EnZymes) databank [15]. This family is a member of clan Glyco hydro tim or TIM barrel glycosyl hydrolase (GH) superfamily, which comprises 26 members, including $\alpha$-amylase and cellulase. The deduced amino acid sequence alignment of $B$. licheniformis mannan endo-1,4$\beta$-mannosidase with other bacterial $\beta$-mannanases from family 26 is shown in Fig. 1. The enzyme shows the classical TIM $(\beta / \alpha) 8$-barrel architecture. The catalytic domains of GH26 members are located at the C-terminus, and conserved amino acid residues of this glycosyl hydrolase family are also shown in Fig. 1. The mannan endo-1,4- $\beta$ mannosidase from $B$. licheniformis is highly similar to ManB from B. subtilis Z-2 [16] and B. subtilis strain 168 [17] with $82 \%$ identity, whereas its similarity to GH26 $\beta$ mannanases from other bacterial species is significantly less (11-20\% identity).

\section{Expression and secretion of mannan endo-1,4- $\beta$ - mannosidase}

The recombinant mannan endo-1,4- $\beta$-mannosidase produced in this study was fused with the E. coli OmpA signal peptide and thereby could be efficiently secreted into the periplasmic space and culture medium as has been previously reported for this expression system and various secreted Bacillus-derived enzymes [13]. Both the efficient expression and extracellular location after induction with IPTG are evident from Fig. 2. At $4 \mathrm{~h}$ after induction, a large fraction of the recombinant enzyme was accumulated in the periplasmic space, and after inducing overnight, more enzymes could be found in the culture medium than in the periplasmic space. Comparison of the yield of recombinant $B$. licheniformis mannan endo$1,4-\beta$-mannosidase in different compartments at various induction conditions in shake flask is given in Table 1 . The highest specific activity could be obtained from perisplasmic extract after induction with $0.5 \mathrm{mM}$ IPTG overnight, whereas the largest total activity could be obtained from the three fractions after induction with 1 mM IPTG for $4 \mathrm{~h}$. Nevertheless, other conditions yield only slightly different results. Routinely, we obtained 45 $50,000 \mathrm{U}$ of total mannan endo-1,4- $\beta$-mannosidase activity from a 1-1 shake flask culture. To prepare the enzyme for purification and analysis in the next step, we preferred to use the cytoplasmic and especially the periplasmic extract, as the enzyme was highly concentrated, facilitating the subsequent affinity purification step. 


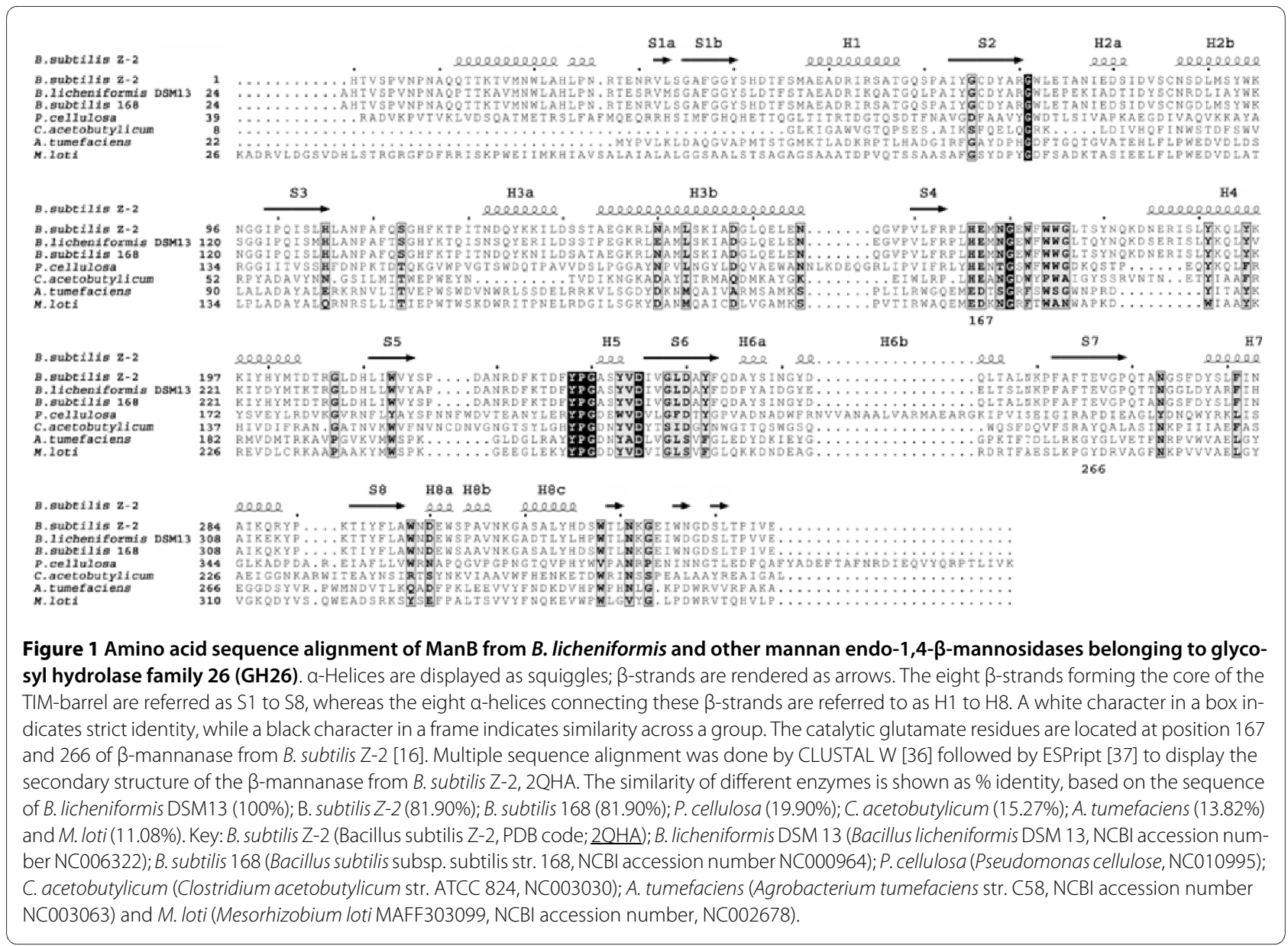

\section{Enzyme purification and assay}

The crude enzyme from the periplasmic extract was used for affinity purification on Ni-NTA agarose. The enzyme could be purified to apparent homogeneity using this one-step purification protocol as shown by SDS-PAGE analysis (Fig. 3, panel A). Mannan endo-1,4- $\beta$-mannosidase activity of the purified enzyme was shown by in-gel activity staining (Fig. 3, panel B) as well as by the standard $\beta$-mannanase assay. Recombinant ManB showed a molecular mass of approximately $45 \mathrm{kDa}$ on SDS-PAGE, confirming the theoretical mass of $41 \mathrm{kDa}$. The specific activity of the homogenous enzyme was $1672 \pm 96 \mathrm{U} / \mathrm{mg}$ under the standard assay conditions. We routinely obtained a total of approximately 40,000 U of purified enzyme (equivalent to $<25 \mathrm{mg}$ ) from $1-1$ cultures.

\section{Effect of $\mathrm{pH}$ and temperature}

The optimal $\mathrm{pH}$ of mannan endo-1,4- $\beta$-mannosidase activity from B. licheniformis was at $\mathrm{pH} 6.0-7.0$ (Fig. 4, panel A). Notably, the enzyme shows a significant activity up to $\mathrm{pH} 9.0$, and is more active at this $\mathrm{pH}$ when using glycine buffer than potassium phosphate buffer. The enzyme was stable within pH 5 - 12 after incubation for $30 \mathrm{~min}$ at $50^{\circ} \mathrm{C}$ (Fig. 4, panel B), and within $\mathrm{pH} 6-9$ after incubation at $50^{\circ} \mathrm{C}$ for $24 \mathrm{~h}$ (Fig. 4, panel C). The optimal temperature for ManB activity was $50-60^{\circ} \mathrm{C}$ for the 5min assay (Fig. 4, panel A). The enzyme was stable up to $55^{\circ} \mathrm{C}$ after incubation for $30 \mathrm{~min}$ at $\mathrm{pH} 6.0$ (Fig. 5, panel B). In addition, it showed a half-life time of activity, $\tau 1 / 2$ of approximately $80 \mathrm{~h}$ at $50^{\circ} \mathrm{C}$ and $\mathrm{pH} 6.0$, while $\tau 1 / 2$ decreased considerably to only $3 \mathrm{~min}$ at $60^{\circ} \mathrm{C}$ (Fig. 5C).

\section{Substrate specificity and kinetic parameters}

The relative activity of ManB from B. licheniformis for various substrates was determined as shown in Table 2 . The enzyme exhibited highest activity on glucomannan prepared from konjac followed by pure 1,4- $\beta$-D-mannan and the galactomannan locust bean gum (LBG). The activity of the enzyme with highly substituted galactomannan from guar gum and copra meal was negligible when using the standard assay. However, we found that partial hydrolysis of copra meal after incubation occurred after incubation of this substrate with the enzyme for 2 to 3 days (data not shown).

Furthermore, the kinetic constants for the hydrolysis of selected substrates were determined. Because of the extremely high viscosity of LBG solutions, especially at higher concentrations necessary for the determination of 
Table 1: Yield of recombinant B. licheniformis mannan endo-1,4- $\beta$-mannosidase in different cell compartments of $E$. coli

\begin{tabular}{|c|c|c|c|c|c|c|c|c|}
\hline \multirow[t]{2}{*}{ Induction } & \multicolumn{2}{|c|}{ Culture supernatant } & \multicolumn{2}{|c|}{ Periplasmic Space } & \multicolumn{2}{|c|}{ Cytoplasm } & \multicolumn{2}{|c|}{ Total } \\
\hline & $4 \mathrm{hr}$ & Ovn & $4 \mathrm{hr}$ & Ovn & $4 \mathrm{hr}$ & Ovn & $4 \mathrm{hr}$ & ovn \\
\hline \multicolumn{9}{|l|}{0.1 mM IPTG } \\
\hline $\begin{array}{l}\text { Total Activity } \\
(\mathrm{U} / \mathrm{L})\end{array}$ & 8,659 & 15,076 & 13,509 & 9,983 & 15,189 & 24,502 & 37,357 & 49,561 \\
\hline $\begin{array}{l}\text { Total Protein } \\
(\mathrm{mg} / \mathrm{L})\end{array}$ & 147 & 170 & 44.5 & 17.8 & 186 & 163 & 378 & 351 \\
\hline $\begin{array}{l}\text { Sp. Activity } \\
\text { (U/L) }\end{array}$ & 58.8 & 89.0 & 304 & 560 & 81.7 & 150 & 99.0 & 141 \\
\hline \multicolumn{9}{|l|}{0.5 mM IPTG } \\
\hline $\begin{array}{l}\text { Total Activity } \\
\text { (U/L) }\end{array}$ & 8,437 & 14,171 & 19,649 & 13,488 & 10,589 & 24,480 & 38,675 & 52,139 \\
\hline $\begin{array}{l}\text { Total Protein } \\
(\mathrm{mg} / \mathrm{L})\end{array}$ & 137 & 156 & 45.0 & 20.5 & 137 & 199 & 319 & 376 \\
\hline Sp. Activity & 61.7 & 91.1 & 437 & 660 & 77.3 & 123 & 121 & 139 \\
\hline
\end{tabular}

$(U / L)$

\section{$1.0 \mathrm{mM} \mathrm{IPTG}$}

Total Activity $\quad 13,561$

14,402

17,647

13,232

24,502

26,632

55,710

54,266

Total Protein 153

(mg/L)

175

39.5

20.2

163

168

356

363

Sp. Activity $\quad 88.9$

82.4

447

656

150

159

157

149

The typical yield of the overexpression of recombinant mannan endo-1,4- $\beta$-mannosidase from B. licheniformis in E. coli grown in 1-liter shaken flask cultures is reported. Cells were cultivated and enzymes from various compartments were harvested after induction for 4 and $20 \mathrm{~h}$ as described in Material and Method.

the kinetic constants, low-viscosity LBG was prepared by partial hydrolysis [18] and used as a substrate in addition to glucomannan from konjac and pure 1,4- $\beta$-D-mannan. When present in saturating concentrations, low-viscosity LBG was the preferred substrate as judged both from the highest turnover number kcat and specificity constant kcat/Km (Table 3).

\section{Product analysis by thin-layer chromatography}

Product analysis by TLC after hydrolysis of various substrates confirmed that the recombinant enzyme is indeed an endo- $\beta$-mannanase. Various manno-oligosaccharide products (M2 - M6) as well as mannose were found after enzymatic hydrolysis of locust bean gum and mannan (Fig. 6). When mannohexaose (M6) was used as a substrate (Fig. 7), the main products were M2, M3 and M4, suggesting random hydrolysis of this oligosaccharide. After extensive overnight digestion, mannose (M1) could be observed as well. Analysis of hydrolysis products when using different manno-oligosaccharides (M2 - M5) as substrates revealed that ManB from B. licheniformis cannot cleave mannobiose, mannotriose or mannotetraose, whereas mannopentaose was hydrolysed only after extensive incubation overnight, generating M2 and M3 as products (Fig. 7).

\section{Discussion}

B. licheniformis strain DSM13 was used as the source for the isolation of the mannan endo-1,4- $\beta$-mannosidase gene, $\operatorname{man} B$ since this strain has been used extensively for large-scale production of various industrial enzymes including serine protease (subtilisin) or $\alpha$-amylase [9]. The genome of strain DSM13 has recently been sequenced, and a number of new genes of potential biotechnological applications have been identified [10]. The mannan endo-1,4- $\beta$-mannosidase gene was cloned by PCR cloning, using primers designed from the published genome database. This is the first report on the cloning, expression, and characterization of recombinant mannan 

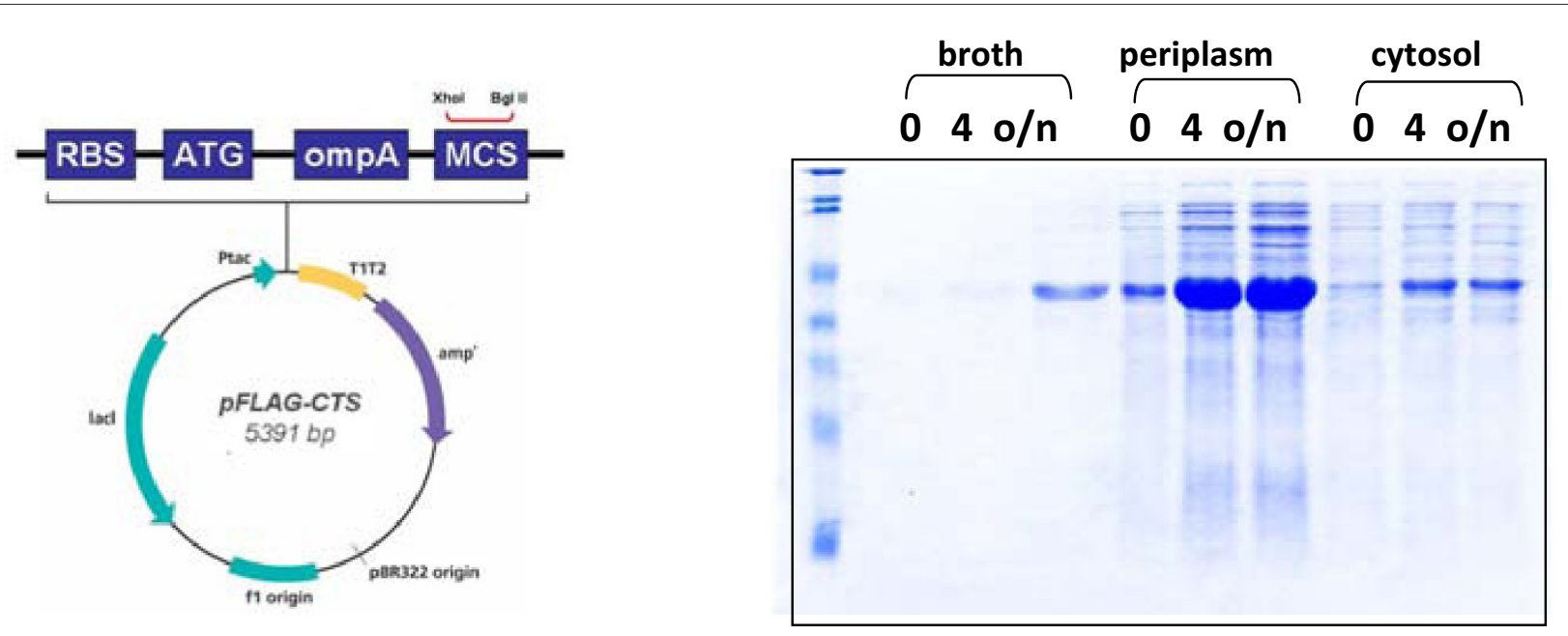

Figure 2 Expression and secretion of recombinant mannan endo-1,4- $\boldsymbol{\beta}$-mannosidase (ManB) from B. licheniformis. A) The $p F L A G-C T S$ system (Sigma) was used for the expression of recombinant $\beta$-mannanase. Enzyme expression was under the control of tac promoter, which can be induced for overexpression by IPTG. The vector contains the ampicillin resistant gene, and a hexahistidine tag was incorporated C-terminally. The mature enzyme was fused to the E. coli OmpA signal peptide (shown in a box) for secretion into the periplasmic space. B) Cells were grown until $\mathrm{OD}_{600}$ reach $\sim 1.0$ before IPTG was added to a final concentration of $1 \mathrm{mM}$, and incubation continued at $28^{\circ} \mathrm{C}$. Samples were taken at $0,4 \mathrm{~h}$, and overnight ( $20 \mathrm{~h}, \mathrm{o} /$ n) after induction with IPTG. Culture supernantant, periplasmic and cytosolic fractions were prepared as described in Material and Method. Approximately equal amounts of total protein in the periplasmic and cytosolic fraction were loaded onto each lane.

endo-1,4- $\beta$-mannosidase from $B$. licheniformis. Other reports on recombinant Bacillus mannan endo-1,4- $\beta$ mannosidases were dealing with enzymes from $B$. subtilis [16,19-23]. B. stearothermophilus [24], and B. circulans [25].

Mannan endo-1,4- $\beta$-mannosidases can be classified into two distinct families, glycosyl hydrolase $(\mathrm{GH})$ family 5 and 26, based on amino acid sequence similarities and hydrophobic cluster analysis [14]. Family GH5 was formerly known as cellulase family $\mathrm{A}$ and encompasses

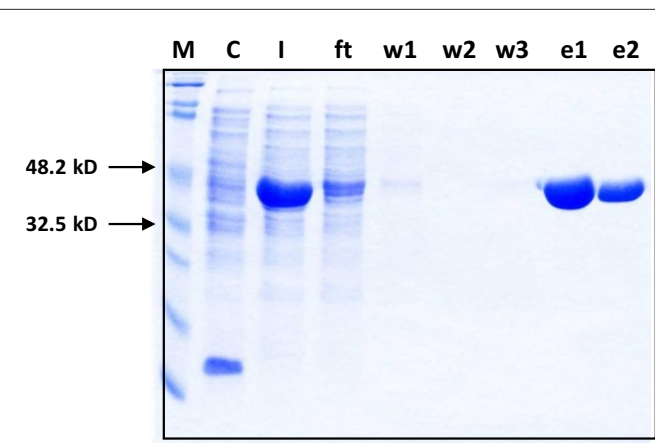

A

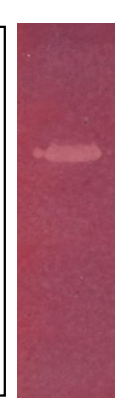

B
Figure 3 Coomassie staining and zymogram analysis of purified recombinant mannan endo-1,4- $\beta$-mannosidases from $B$. licheniformis. SDS-PAGE analysis of purified recombinant $\beta$-mannanase is shown in panel A. M, marker; C, control E. coli lysate; I, input (crude extract); Ft, flow through; w1-3, wash 1-3; e1-2, enzyme from 1st and 2nd elution. Panel B illustrates zymogram analysis of the purified enzyme. Only $1 / 1000$ of the amount used in the left panel was loaded onto the gel. White bands indicate mannan endo-1,4- $\beta$-mannosidase activity. diverse enzymes [26], whereas glycosyl hydrolase family 26 comprises only members with mannan endo-1,4- $\beta$ mannosidase (EC 3.2.1.78) and $\beta-1,3$-xylanase (EC 3.2.1.32) activities [14]. Amino acid sequence analysis of mannan endo-1,4- $\beta$-mannosidase from $B$. licheniformis revealed that the enzyme belongs to family GH26. In addition, we also cloned and expressed the mannan endo$1,4-\beta$-mannosidase gene $(\operatorname{man} B)$ from $B$. licheniformis strain DSM 8785. The two enzymes have only one amino acid different, and the properties of these two heterologously expressed recombinant enzymes are identical (data not shown).

The expression and production of the recombinant mannan endo-1,4- $\beta$-mannosidase reported here is based on a previously published $E$. coli expression system [13]. The mature mannan endo-1,4- $\beta$-mannosidase gene was fused to the $E$. coli ompA signal sequence and is under the control of tac promoter. Thus, the enzyme could be efficiently secreted, and harvested from the culture medium, periplasm, or cell lysate fraction, depending on the culture condition. When the gene was induced for over-expression by $1 \mathrm{mM}$ IPTG for $3-4 \mathrm{~h}$, we routinely obtained about $25 \mathrm{mg}$ of recombinant enzyme from the cytoplasmic and periplasmic extracts of 1-liter cultures, which contain more than 40,000 units of purified enzyme. Under the induction with IPTG, a significant fraction of the enzyme was still found in the cytosol. This could indicate that the over-expressed enzyme possibly saturates the bacterial secretion system [27]. It should be mentioned that no optimization aiming at increased 


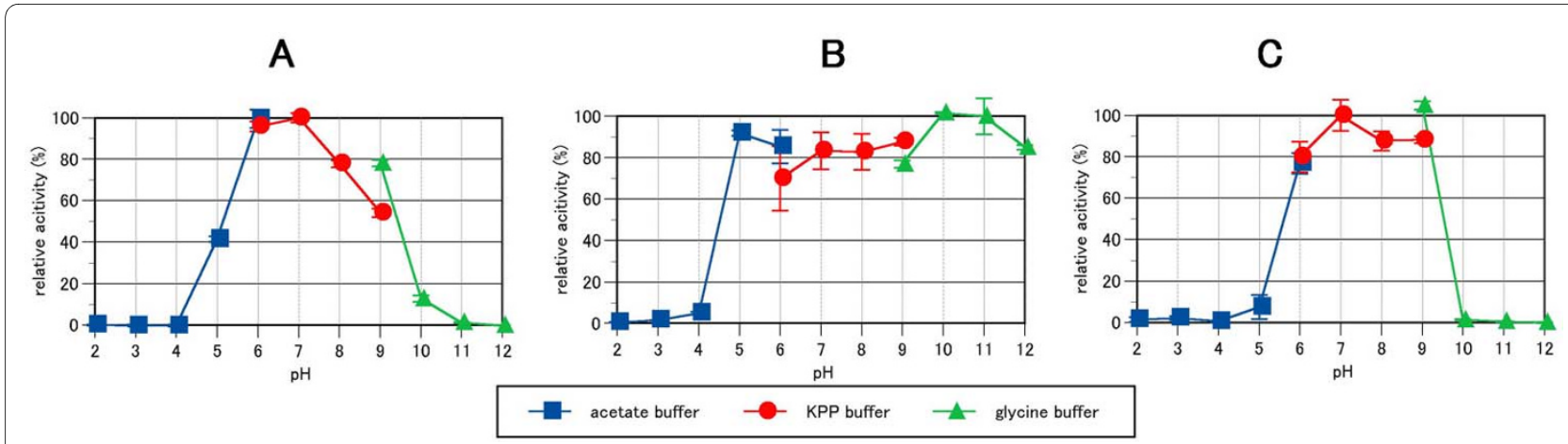

Figure 4 Effect of $\mathrm{pH}$ on the activity $(\mathrm{A})$ and stability $(\mathrm{B}, \mathrm{C})$ of $\boldsymbol{B}$. licheniformis mannan endo-1,4- $\boldsymbol{\beta}$-mannosidase. The optimal pH was determined at $50^{\circ} \mathrm{C}$ using $0.5 \%$ LBG in $50 \mathrm{mM}$ of different buffers (A). The $\mathrm{pH}$ stability was determined by measuring the remaining activity after incubation at various $\mathrm{pH}$ values at $50^{\circ} \mathrm{C}$ for $30 \mathrm{~min}$ (B) and $24 \mathrm{~h}$ (C). The buffers used were acetate buffer (black square) from pH 2 - 6; potassium phosphate buffer; KPP (black circle) from pH 6 - 9; and glycine buffer (black triangle) from pH 9 - 12.

enzyme yields was performed. Thus, by applying optimized culture and induction conditions together with a suitable fermentation strategy, considerably higher recombinant protein yields can be expected. Thus, our expression system is highly efficient for expression of bacterial $\beta$-mannanses and should be applicable for other enzymes as well. More importantly, the extracellular location of the enzyme might be of interest for large-scale cultivations as it circumvents the necessity of cell disruption.

Mannan endo-1,4- $\beta$-mannosidases are active on various mannans and substituted mannans, but display negligible to low activity towards other plant cell wall polysaccharides $[3,28]$. The enzymes randomly hydrolyse $\beta$-1,4-linkages in diverse substrates such as pure mannans, galactomannans, glucomannans and galactoglucomannans [4]. In this study, we found that B. licheniformis ManB shows the highest relative activity for glucomannan prepared from konjac followed by pure low-molecular mass 1,4- $\beta$-D-mannan of DP (degree of polymerization) $<15$ and high-viscosity (high molecular mass) locust bean gum. However, we were not able to detect notable activity for guar gum and copra meal using the standard assay of 5-min incubation. Based on the kinetic characterization and judged from the specificity constant $\mathrm{kcat} / \mathrm{Km}$, the galactomannan locust bean gum (low viscosity) is the preferred substrate, however the differences in the specificity constant are not very pronounced when compared to konjac glucomannan and pure mannan. Apparently, B. licheniformis ManB prefers soluble and low-substituted mannan substrates. This is evident from a comparison of the relative activity on soluble LBG, a galactomannan from Ceratonia siliqua with a mannose-to-galactose ratio of 4:1, and soluble guar gum, a galactomannan from Cymopsis tetragonoloba with a mannose-to-galactose ratio of 2:1 [1]. While the former is a good substrate, the activity on the latter is negligible during the 5-min standard assay. Similarly, activity on copra mannan, an insoluble galactomannan with a very low degree of galactosyl substitution, is very low [29].

There have been a number of reports on the characterization of mannan endo-1,4- $\beta$-mannosidases, both native and recombinant, from various organisms as summarized in Additional file 1. The $\mathrm{pH}$ and temperature optima as well as the stability of the enzymes are clearly varying, depending on the sources of the enzymes. Typically, the enzymes from non-bacterial sources show lower $\mathrm{pH}$ and temperature optima as well as lesser stability (See Additional file 1). The specific activity (from $3.8-8300 \mathrm{U} / \mathrm{mg}$ ) and kinetic parameters ( $\mathrm{Km}$ ranging from 0.3-10.2, Vmax from 3.8-2000) of the mannan endo-1,4- $\beta$-mannosidases from various sources, when using LBG as a substrate, vary greatly as shown in Additional file 1 . This obviously reflects differences in the structure of the enzymes, for example highly thermostable mannan endo- $1,4-\beta$-mannosidase tend to have lower specific activity compared to their mesophilic counterparts [24,30,31]. In this respect, the B. licheniformis ManB described in our report is characterized by a very high specific activity of $1672 \mathrm{U} / \mathrm{mg}$ as well as by a relatively high stability. However, when comparing different mannan endo-1,4- $\beta$-mannosidases it is important to note that locust bean gum, which is a standard substrate for measuring mannan endo- $1,4-\beta$-mannosidase activity, is highly viscous and difficult to prepare. It can be assumed that the large discrepancy of enzyme activity in some of the reports can in part result from various techniques used in substrate preparation. For example we were not able to estimate with confidence the kinetic parameters when using high-viscosity, commercial LBG as a substrate. Thus, only the kinetic parameters when using low-viscosity LBG, low-viscosity glucomannan from konjac, and $\beta$-mannan are reported here. 
A

B
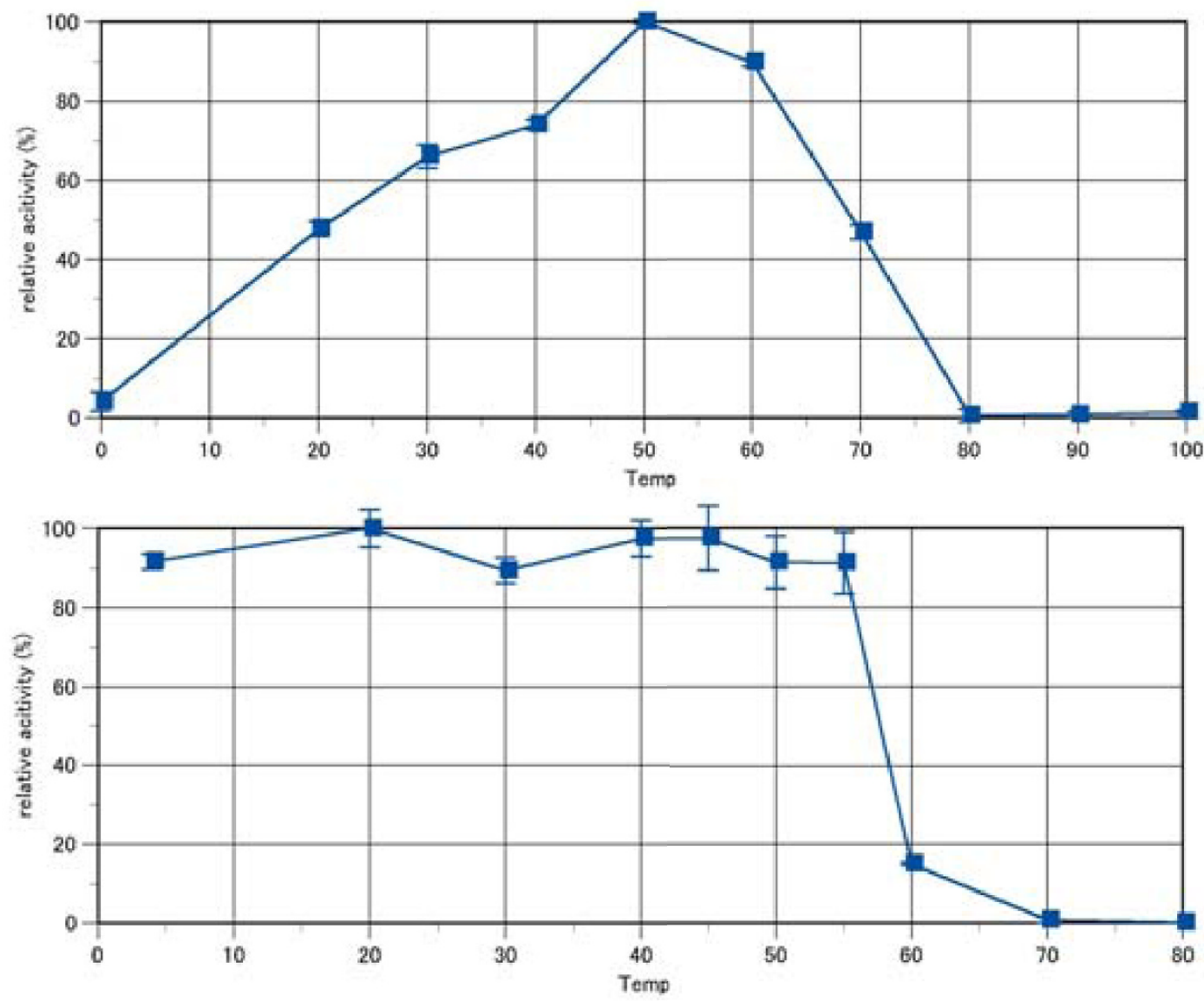

C
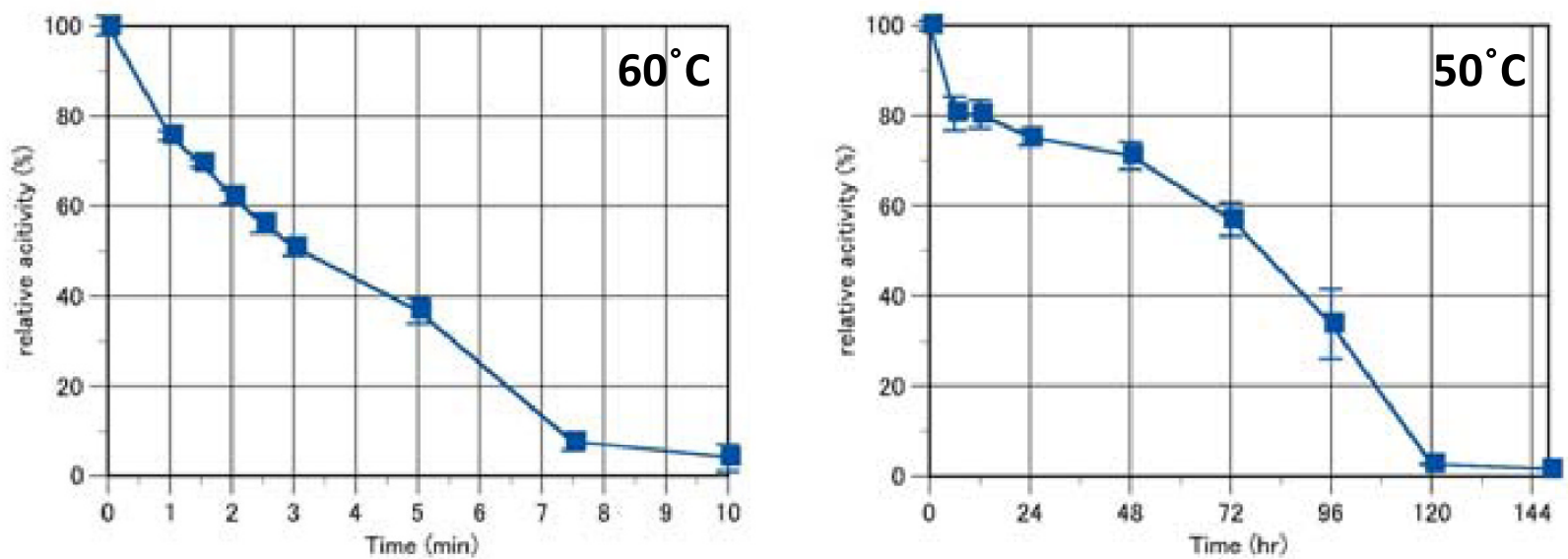

Figure 5 Effect of temperature on activity $(A)$ and stability $(B, C)$ of $B$. licheniformis mannan endo-1,4- $\boldsymbol{\beta}$-mannosidase. The optimal temperature was determined using $0.5 \%$ LBG in 50 mM citrate buffer, pH 6.0 (A). The temperature stability was determined by measuring the remaining activity after incubation without substrate at various temperatures at pH 6.0 for $30 \mathrm{~min}$, and measuring the residual activity using the standard assay (B). Panel $\mathrm{C}$ illustrates the remaining enzyme activity after incubation at $60^{\circ} \mathrm{C}$ (left) and $50^{\circ} \mathrm{C}$ (right) at various time points.

TLC analysis of hydrolysis products confirmed that recombinant $B$. licheniformis mannanse is an endo-mannanase, which can efficiently and randomly cleave higher molecular weight mannans containing more than six mannose monomers. The enzyme could only cleaved mannopentaose after an extended incubation for $12 \mathrm{~h}$ and had no detectable activity against mannobiose, -triose or -tetraose. This property suggests that this enzyme 
Table 2: Substrate specificity of $B$. licheniformis mannan endo-1,4- $\beta$-mannosidase

\begin{tabular}{|c|c|}
\hline Substrate & Relative activity (\%) \\
\hline Glucomannan (konjac) & 219 \\
\hline 1,4- $\beta$-D-Mannan & 166 \\
\hline Locust bean gum & 100 \\
\hline Guar gum & nd \\
\hline Copra meal & nd \\
\hline \multicolumn{2}{|c|}{$\begin{array}{l}\text { The activity of mannan endo-1,4- } \beta \text {-mannosidase from } B \text {. } \\
\text { licheniformis was determined under standard assay conditions } \\
\text { using each substrate at a concentration of } 5 \mathrm{~g} / \mathrm{l} \text {. The relative } \\
\text { activity with the standard substrate locust bean gum (high } \\
\text { viscosity) was defined as } 100 \% \text {. } \\
\text { nd: no apparent activity at standard assay condition was } \\
\text { detected. }\end{array}$} \\
\hline
\end{tabular}

could be applicable for the generation of prebiotic manno-oligosaccharides (MOS), as higher oligosaccharides formed will not be hydrolyzed further. Extensive hydrolysis of cheap and commercial available locust bean gum can therefore result in a mixture of MOS containing various oligosaccharides that may have a diverse prebiotic and anti-obesity [8] effects in different regions of the gut. Higher oligosaccharides are currently discussed as prebiotics with enhanced persistence that can reach more distal regions of the gut, and thus show their positive effect also in that region [32].

\section{Conclusion}

Our results demonstrate an efficient system for expression and secretion of a relatively thermo- and alkali-stable $\beta$-mannanase from $B$. licheniformis, which is suitable for industrial applications. In addition, the expression and secretion system that is used in this study could be adopted for production of other enzymes as well.

\section{Methods}

Bacterial strains and culture conditions

Bacillus licheniformis DSM13 (ATCC 14580) was obtained from DSMZ; German Culture Collection of Microorganisms and Cell Cultures (Braunschweig, Germany). Cells were grown at $37^{\circ} \mathrm{C}$ and kept in $\mathrm{M} 1$ medium. Escherichia coli DH5a (Life Technologies) was used in the molecular cloning experiments, whereas E. coli Top 10 (Invitrogen) was used for expression of the recombinant enzyme. The $E$. coli strains were grown in Luria broth (LB) containing $100 \mu \mathrm{g} / \mathrm{ml}$ of ampicillin for maintaining the plasmid.

\section{Molecular cloning of mannan endo-1,4- $\beta$-mannosidase from Bacillus licheniformis}

The gene of the mature mannan endo-1,4- $\beta$-mannosidase was cloned by a PCR-based method. The primers B.liManfwXhoI: CTG TGC CTC GAG CAC ACA CCG TTT CTC CGG TG, and B.liManrv6HiBgl2: CTG TGC AGA TCT TCA ATG GTG ATG GTG ATG GTG TTC CAC GAC AGG CGT CAA AGA ATC GCC were used for PCR amplification of $\operatorname{manB}$. These primers were designed using the published sequence from the genomic database of $B$. licheniformis DSM13 (NCBI accession number. NC006322, REGION: 739316740398), and were compatible with the XhoI and BglII cloning sites of pFLAG-CTS expression vectors (Sigma). The DNA encoding native signal peptides were omitted, and the gene of the mature enzyme was fused with the E. coli OmpA signal peptide instead in order to enable efficient secretion into the periplasm and culture media. In addition, DNA encoding a hexahistidine tag was incorporated into the reverse primers to generate $6 \times$ His tagged recombinant enzymes for further purification. PCR reactions were performed according to the recommendations from the manufacture in a thermal cycler from $\mathrm{MJ}$ Research. Templates were prepared by boiling a single colony of B. licheniformis in $100 \mu \mathrm{l}$ of water for $5 \mathrm{~min}$, and $50 \mu \mathrm{l}$ of that solution were directly used in the PCR reaction. The PCR reaction (total volume of $100 \mu \mathrm{l}$ ) consisted of $0.5 \mu \mathrm{M}$ of primers, $0.2 \mathrm{mM}$ dNTP, 3 units of Pfu DNA polymerase (Promega), and $10 \times$ reaction buffer, provided

Table 3: Kinetic parameters of the purified mannan endo-1,4- $\beta$-mannosidase

\begin{tabular}{|c|c|c|c|c|}
\hline Substrate & $\begin{array}{l}\text { Vmax } \\
\qquad(\mu \mathrm{mol} \min -1 \mathrm{mg}-1)\end{array}$ & $\begin{array}{l}\mathrm{Km} \\
\quad(\mathrm{mg} \mathrm{ml}-1)\end{array}$ & $\begin{array}{l}\text { kcat } \\
\text { (s-1) }\end{array}$ & $\begin{array}{l}\text { kcat/Km } \\
\text { (mg-1s-1ml) }\end{array}$ \\
\hline Glucomannan & 30,400 & 14.9 & 21,000 & 1,410 \\
\hline LBG(low viscosity) & 45,300 & 17.5 & 31,200 & 1,790 \\
\hline$\beta$-D-Mannan & 26,400 & 15.2 & 18,200 & 1,200 \\
\hline
\end{tabular}



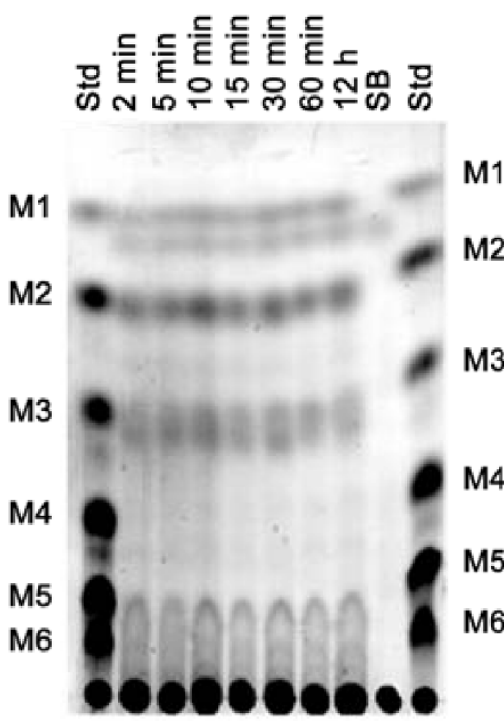

Locust bean gum

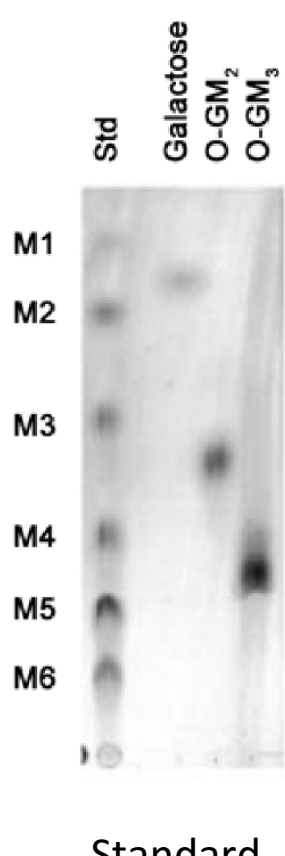

Standard
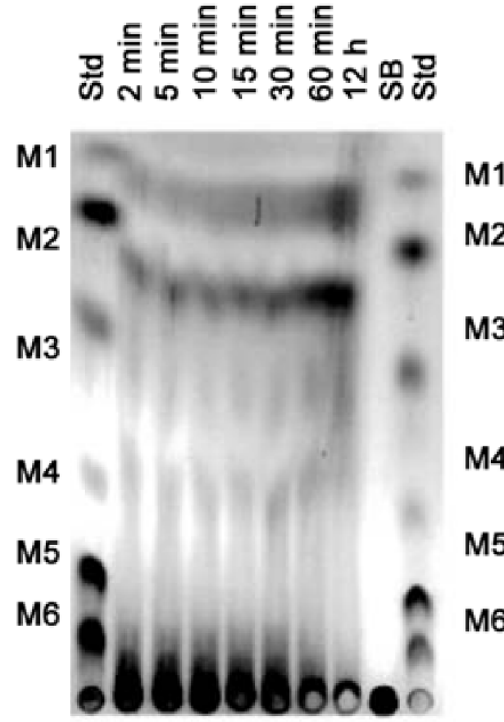

Mannan

Figure 6 Thin layer chromatography analysis of hydrolysis products using LBG and Mannan as substrates. Products from LBG and mannan hydrolysis at various time points are illustrated. Std: a standard mixture of M1 - M6; 2 min, 5 min, $10 \mathrm{~min}, 15 \mathrm{~min}, 30 \mathrm{~min}, 60 \mathrm{~min}, 12 \mathrm{~h}$ are the reaction products after incubation at 2, 5, 10, 15, 30 and $60 \mathrm{~min}$, and $12 \mathrm{~h}$ respectively; SB: substrate blank.

by the manufacturer. The amplifications were done as follows: initial DNA denaturation at $95^{\circ} \mathrm{C}$ for $2 \mathrm{~min} ; 30$ cycles of denaturation at $95^{\circ} \mathrm{C}$ for $45 \mathrm{sec}$, annealing at $58^{\circ} \mathrm{C}$ for $1 \mathrm{~min}$, extension at $72^{\circ} \mathrm{C}$ for $2.5 \mathrm{~min}$, and a final extension at $72^{\circ} \mathrm{C}$ for $10 \mathrm{~min}$. The PCR products were separated on $1 \%$ agarose gels containing ethidium bromide and visualized under a UV transilluminator. PCR products were purified using PCR purification kits (Qiagen, Germany). The PCR products were then cut with appropriate restriction enzymes (XhoI and $B g l \mathrm{II})$ and ligated into the pFLAG-CTS expression vector that has been cut with corresponding enzymes. The ligation reactions were transformed into E. coli DH5 $\alpha$. The DNA sequence and the integrity of the constructs were determined by automated DNA sequencing (Macrogen, Korea).

\section{Expression of recombinant enzymes}

Freshly transformed E. coli Top 10 harbouring the recombinant $\operatorname{man} B$ gene was inoculated into $5 \mathrm{ml}$ of LB broth containing $100 \mu \mathrm{g} / \mathrm{ml}$ of ampicillin at $37^{\circ} \mathrm{C}$ for $16 \mathrm{~h}$. After

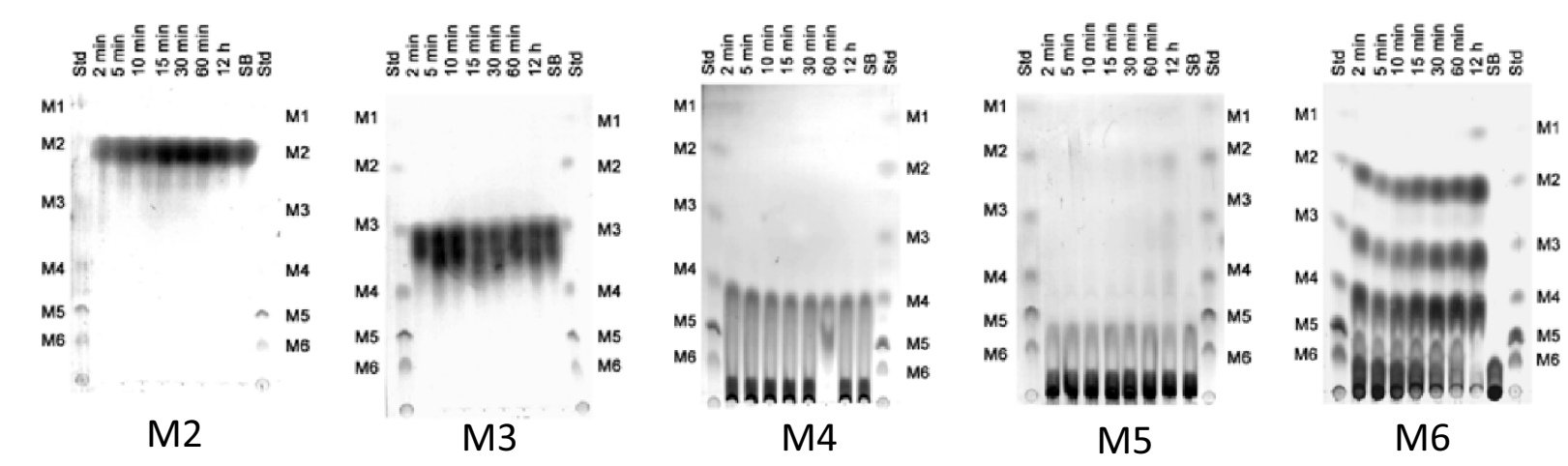

Figure 7 Thin layer chromatography analysis of hydrolysis products using various manno-oligosaccharides as substrates. Hydrolysis products when using mannobiose (M2), mannotriose (M3), mannotetraose (M4), mannopentaose (M5) and mannohexaose (M6) as substrates are shown. Std: a standard mixture of M1 - M6; $2 \mathrm{~min}, 5 \mathrm{~min}, 10 \mathrm{~min}, 15 \mathrm{~min}, 30 \mathrm{~min}, 60 \mathrm{~min}, 12 \mathrm{~h}$ are the reaction products after incubation at 2, 5, 10, 15, 30 and $60 \mathrm{~min}$, and $12 \mathrm{~h}$ respectively; SB: substrate blank. 
that, $1 \mathrm{ml}$ of overnight culture was inoculated into 250$1000 \mathrm{ml}$ of LB broth containing $100 \mu \mathrm{g} / \mathrm{ml}$ ampicillin and grown at $37^{\circ} \mathrm{C}$ until the optical density at $600 \mathrm{~nm}$ reached 1.0 - 1.5. Then, IPTG was added into the culture broth to a final concentration of $0.1-1.0 \mathrm{mM}$. The culture was subsequently incubated with vigorous shaking $(250 \mathrm{rpm})$ at $26-28^{\circ} \mathrm{C}$ (room temperature) for $3-4 \mathrm{~h}$. The culture was collected and chilled in an icebox for $5 \mathrm{~min}$ and centrifuged at $2,000 \times \mathrm{g}$ for $10 \mathrm{~min}$ at $4^{\circ} \mathrm{C}$ to separate cells and supernatant. To extract the periplasmic content, the cells were resuspended in $2.5 \mathrm{ml}$ of cold $\left(4^{\circ} \mathrm{C}\right)$ spheroplast buffer [100 mM Tris-HCl, pH 8.0, 0.5 mM EDTA, $0.58 \mathrm{M}$ sucrose, and $20 \mu \mathrm{g} / \mathrm{ml}$ phenylmethylsulfonyl fluoride (PMSF)]. After incubation for $5 \mathrm{~min}$ on ice, bacterial cells were collected by centrifugation at $8,000 \times \mathrm{g}$ at $4^{\circ} \mathrm{C}$ for 10 min and re-suspended in 1-2 $\mathrm{ml}$ of ice-cold sterile water supplemented with $1 \mathrm{mM} \mathrm{MgCl}$ and incubated on ice for 5 minutes with frequent shaking. The supernatant of approximately $1-2 \mathrm{ml}$ was then collected by centrifugation at $8,000 \times \mathrm{g}$ at $4^{\circ} \mathrm{C}$ for $15 \mathrm{~min}$ as the periplasmic fraction. To extract the cell lysate, the precipitated cells from the previous step were washed once with lysis buffer (50 $\mathrm{mM}$ Tris- $\mathrm{HCl}+0.5 \mathrm{mM}$ EDTA), resuspended in $1-2 \mathrm{ml}$ of lysis buffer, and sonicated (Ultrasonic Processor; 60 amplitude, pulser $6 \mathrm{sec}$, for $2 \mathrm{~min}$ ) on ice. The cell debris was then spun down at $8,000 \times \mathrm{g}$ and the supernatant was collected as the cell lysate.

\section{Purification of recombinant mannan endo-1,4- $\beta$ - mannosidase}

Immobilized metal affinity chromatography (IMAC) was used for purification of $6 \times$ His-tagged recombinant $\beta$ mannanase by gravity-flow chromatography, using $\mathrm{Ni}$ NTA Agarose according to the manufacturer protocol (Qiagen). The periplasmic extract was loaded onto a column and washed three times with increasing concentrations of imidazole of 5, 10 and $20 \mathrm{mM}$. The enzyme was then eluted by elution buffer containing $250 \mathrm{mM}$ imidazole, and dialyzed using a dialysis membrane (Pierce Biotechnology, 10-kDa molecular-weight cutoff) to remove imidazole.

\section{Gel electrophoresis and zymogram analysis}

Denaturing sodium dodecyl sulfate-polyacrylamide gel electrophoresis (SDS-PAGE) was performed according to the method of Laemmli [33], in a $12 \%$ (w/v) polyacrylamide gel. The protein samples were briefly heated $(3 \mathrm{~min})$ in the loading buffer at $100^{\circ} \mathrm{C}$ using a heat block (Eppendorf). Protein bands were visualized by staining with Coomassie brilliant blue R-250. The molecular weight markers were from Biorad.

A zymogram of mannan endo-1,4- $\beta$-mannosidase activities was generated by an in-gel activity assay using $0.25 \%$ locust bean gum as substrate, copolymerized with
$10 \%(\mathrm{w} / \mathrm{v})$ polyacrylamide. The enzyme samples were mixed with the loading buffer in the absence of reducing agent, and then applied onto a polyacrylamide gel. After electrophoresis, the gel was soaked in $2.5 \%$ Triton X-100 for $30 \mathrm{~min}$ at $4{ }^{\circ} \mathrm{C}$, and incubated in sodium phosphate buffer $\mathrm{pH} 7.0$ at $50^{\circ} \mathrm{C}$ for $1 \mathrm{~h}$. The gel was then rinsed with de-mineralized water, stained with $0.1 \%$ Congo red solution and gentle shaking for 20 min prior to destaining with $1 \mathrm{M} \mathrm{NaCl}$ for 20-30 min, and thereafter was placed in 5\% acetic acid for $3 \mathrm{~min}$ (optional). Mannan endo-1,4$\beta$-mannosidase activity was detected as clear zones against red (after staining with Congo red) or blue background (after soaking in 5\% acetic acid).

\section{Protein determination}

Protein concentration was determined by the method of Bradford [34] using bovine serum albumin as standard.

\section{Enzyme assays}

Standard mannan endo-1,4- $\beta$-mannosidase activity was assayed using the dinitrosalicylic acid (DNS) method [35]. The substrate, $0.5 \%$ locust bean gum (Sigma), was dissolved in $50 \mathrm{mM}$ sodium citrate buffer, $\mathrm{pH} 6.0$ by homogenizing at $80^{\circ} \mathrm{C}$, heated to the boiling point, cooled and stored overnight with continuous stirring. After that insoluble was removed by centrifugation. An appropriately diluted enzyme solution $(0.1 \mathrm{ml})$ was incubated with $0.9 \mathrm{ml}$ of the substrate solution at $50^{\circ} \mathrm{C}$ for exactly $5 \mathrm{~min}$. The amount of reducing sugars liberated in the enzyme reaction was assayed by mixing $100 \mu \mathrm{l}$ of the enzyme reaction with $100 \mu \mathrm{l}$ DNS solution, heating at $100^{\circ} \mathrm{C}$ for $20 \mathrm{~min}$, cooling on ice, and diluting with $300 \mu \mathrm{l}$ of de-ionized water before measuring the absorbance at $540 \mathrm{~nm}$. One unit of mannan endo- $1,4-\beta$-mannosidase activity is defined as the amount of enzyme that liberates $1 \mu \mathrm{mol}$ of reducing sugar (using D-mannose as a standard) per minute under the experimental conditions given.

\section{Effect of $\mathrm{pH}$ and temperature on enzyme activity}

The optimal $\mathrm{pH}$ of mannan endo-1,4- $\beta$-mannosidase activity was measured between $\mathrm{pH} 2.0-12.0$ under standard assay condition, using three buffer systems (each 50 $\mathrm{mM})$ : sodium acetate ( $\mathrm{pH} 2.0-6.0)$, potassium phosphate (pH 6.0 - 9.0), and glycine ( $\mathrm{pH} 9.0$ - 12.0). To determine the $\mathrm{pH}$ stability of mannan endo-1,4- $\beta$-mannosidase, enzyme samples were incubated at various $\mathrm{pH}$ values using the same buffer systems as above at $50^{\circ} \mathrm{C}$ for $30 \mathrm{~min}$ or $24 \mathrm{~h}$, and then the remaining enzyme activity was measured under standard assay condition.

The temperature dependence of mannan endo-1,4- $\beta$ mannosidase activity was measured by incubating the enzyme samples with the substrate at temperatures ranging from $4-100^{\circ} \mathrm{C}$ in $50 \mathrm{mM}$ citrate buffer $\mathrm{pH}$ 6.0. Thermal stability of the enzyme was determined by incubating 
enzyme samples in $50 \mathrm{mM}$ citrate buffer, $\mathrm{pH}$ 6.0, at various temperatures ranging from $4-80^{\circ} \mathrm{C}$ for $30 \mathrm{~min}$, then the remaining enzyme activity was measured under standard assay condition. In addition, the thermal inactivation kinetics at 50 and $60^{\circ} \mathrm{C}$ were determined in $50 \mathrm{mM}$ citrate buffer, $\mathrm{pH}$ 6.0, by measuring the residual enzyme activity at certain time points assayed under standard condition.

\section{Relative activity and kinetic parameters}

The relative activity of $B$. licheniformis mannan endo-1,4$\beta$-mannosidase against konjac glucomannan, 1,4- $\beta$-Dmannan, locust bean gum, guar gum and copra meal was determined by pre-incubating $5 \mathrm{mg} / \mathrm{ml}$ of each substrate in $0.1 \mathrm{M}$ phosphate buffer $\mathrm{pH} 7.0$ at $50^{\circ} \mathrm{C}$ for $30 \mathrm{~min}$ with constant agitation using a Thermomixer comfort (Eppendorf AG, Hamburg, Germany). After adding the purified enzyme (276 ng), the reaction was incubated at $50^{\circ} \mathrm{C}$ with shaking for $5 \mathrm{~min}$, and then terminated by boiling for 10 $\mathrm{min}$. The release of reducing sugars was detected by the DNS method as described above. Relative mannan endo$1,4-\beta$-mannosidase activities against various substrates were calculated by converting $\mathrm{A}_{540}$ to $\mu$ moles of mannose released.

For determination of the kinetic parameters, various concentrations of different substrates in $0.1 \mathrm{M}$ phosphate buffer pH 7.0 [konjac glucomannan, low viscosity (3-19.5 $\mathrm{mg} / \mathrm{ml}) ; 1,4-\beta$-D-mannan $(3-30 \mathrm{mg} / \mathrm{ml})$; locust bean gum, low viscosity $(3-39 \mathrm{mg} / \mathrm{ml})$ ] were incubated with the purified mannan endo-1,4- $\beta$-mannosidase $(138 \mathrm{ng})$ at $50^{\circ} \mathrm{C}$ for $5 \mathrm{~min}$. The Vmax and $\mathrm{Km}$ values were calculated by non-linear regression analysis, using the GraphPad Prism software (GraphPad Software Inc., San Diego, CA).

Mannose, konjac glucomannan (low viscosity) and 1,4$\beta$-D-mannan (prepared by controlled hydrolysis of carob galactomannan, DP < 15) were purchased from Megazyme International (Bray, Ireland). Locust bean gum (LBG) was isolated from Ceratonia siliqua seeds (SigmaAldrich). Low-viscosity locust bean gum was prepared according to a previously published protocol [18]. Guar gum was purchased from Sigma-Aldrich, while copra meal was bought from a local market in Nakhon Ratchasima province, Thailand.

\section{Thin-layer chromatography}

Hydrolysis of $15 \mathrm{mM}$ substrates (manno-oligosaccharides M2-M6), $0.1 \mathrm{mg}$ LBG (high viscosity) and $0.1 \mathrm{mg}$ of 1,4$\beta$-D-mannan by mannan endo- $1,4-\beta$-mannosidase was carried out in a 30- $\mu \mathrm{l}$ reaction mixture, containing $0.1 \mathrm{M}$ phosphate buffer, pH 7.0, and $13.8 \mathrm{ng}$ (for M2 - M6), 276 ng (for LBG) or $2.76 \mu \mathrm{g}$ (for 1,4- $\beta$-D-mannan) of purified enzyme. The reaction mixture was incubated at $50{ }^{\circ} \mathrm{C}$ with shaking for $2,5,10,15,30,60 \mathrm{~min}$, and $12 \mathrm{~h}$ prior to termination of the hydrolysis reaction by boiling for 5 min. A sample of each reaction mixture was applied five times (one $\mu \mathrm{l}$ each) to a silica TLC plate $(6.0 \times 10.0 \mathrm{~cm})$, and then chromatographed twice $(2 \mathrm{~h}$ each) using a mobile phase containing n-propanol: ethanol: water $(7: 1: 2)(\mathrm{v} / \mathrm{v})$, followed by spraying with $5 \%$ sulphuric acid and heating at $180^{\circ} \mathrm{C}$ for $3 \mathrm{~min}$. A mixture of M1-M6 (5 nmol each) was used as standard. Manno-oligosaccharides (M2-M6), galacto-manno-oligosaccharides (OGM2 and OGM3), mannose and galactose were from Megazyme, and locust bean gum was from Sigma-Aldrich. Silicagel 60 F254 aluminum sheet, n-propanol and ethanol were purchased from Merck (Damstadt, Germany).

\section{Additional material}

Additional file 1 Properties of various mannan endo-1,4- $\beta$-mannosidases; pdf format; $A$ summary of properties of different mannan endo-1,4- $\beta$-mannosidases, i.e. Source, GH family, $\mathrm{pH}$ and temperature optima, yield, stability, specific activity, kinetic parameter using LBG as substrate, and reference [38-50].

Competing interests

The authors declare that they have no competing interests.

\section{Authors' contributions}

CS performed amino acid sequence analysis, purified and analyzed the enzyme. BB expressed and characterized the enzyme properties. DH supervised enzyme characterization, co-designed experiments, evaluated the data, and edited the manuscript. MY conceived of the study, participated in cloning and expression of the enzymes, and wrote the manuscript. All authors read and approved the final manuscript.

\section{Acknowledgements}

This research was supported by ASEAN-EU University Network Programme (AUNP), National research council of Thailand (NRCT), and Suranaree University of Technology (SUT). We would like to thank Miss Suphap Emrat, Miss

Sasithorn Lapboonrueng, and Miss Phakaimas Phitngam for excellent technical assistances.

\section{Author Details}

1Synchrotron Light Research Institute (Public Organization), 111 University Avenue, Nakhon Ratchasima, Thailand, ${ }^{2 S c h o o l ~ o f ~ B i o t e c h n o l o g y, ~ I n s t i t u t e ~ o f ~}$ Agricultural Technology, Suranaree University of Technology, 111 University Avenue, Nakhon Ratchasima, Thailand and ${ }^{3}$ BOKU, University of Natural Resources and Applied Life Sciences, Vienna, Austria

Received: 18 January 2010 Accepted: 11 April 2010 Published: 11 April 2010

\section{References}

1. Gübitz G, Sachslehner A, Haltrich D: Microbial mannanases: substrates, production and application. Glycosyl Hydrolases for Biomass Conversion: 2001; Washington, DC: ACS Symposium Series, American Chemical Society 2001, 769:239-262.

2. Sanchez C: Lignocellulosic residues: biodegradation and bioconversion by fungi. Biotechnol Adv 2009, 27(2):185-194.

3. Braithwaite KL, Black GW, Hazlewood GP, Ali BR, Gilbert HJ: A nonmodular endo-beta-1,4-mannanase from Pseudomonas fluorescens subspecies cellulosa. Biochem J 1995, 305(Pt 3):1005-1010.

4. Dhawan S, Kaur J: Microbial mannanases: an overview of production and applications. Crit Rev Biotechnol 2007, 27(4):197-216.

5. Biggs $P$, Parsons $C M$ : The effects of several oligosaccharides on true amino acid digestibility and true metabolizable energy in 
cecectomized and conventional roosters. Poult Sci 2007, 86(6):1161-1165.

6. Gibson GR, McCartney AL, Rastall RA: Prebiotics and resistance to gastrointestinal infections. Br J Nutr 2005, 93(Suppl 1):S31-34.

7. Rastall RA, Gibson GR, Gill HS, Guarner F, Klaenhammer TR, Pot B, Reid G, Rowland IR, Sanders ME: Modulation of the microbial ecology of the human colon by probiotics, prebiotics and synbiotics to enhance human health: an overview of enabling science and potential applications. FEMS Microbiol Ecol 2005, 52(2):145-152.

8. Smith DL Jr, Nagy TR, Wilson LS, Dong S, Barnes S, Allison DB: The Effect of Mannan Oligosaccharide Supplementation on Body Weight Gain and Fat Accrual in C57BI/6J Mice. Obesity (Silver Spring) 2009.

9. Schallmey M, Singh A, Ward OP: Developments in the use of Bacillus species for industrial production. Can J Microbiol 2004, 50(1):1-17.

10. Veith B, Herzberg C, Steckel S, Feesche J, Maurer KH, Ehrenreich P, Baumer $\mathrm{S}$, Henne A, Liesegang H, Merkl R, et al:: The complete genome sequence of Bacillus licheniformis DSM13, an organism with great industrial potential. J Mol Microbiol Biotechnol 2004, 7(4):204-211.

11. Araujo A, Ward P: Hemicellulases of Bacillus species: preliminary comparative studies on production and properties of mannanase and galactanases. Journal of Applied Bacteriology 1990, 68:253-261.

12. Zhang J, He Z, Hu K: Purification and characterization of $\beta$-mannanase from Bacillus licheniformis for industrial use. Biotechnology Letters 2000 22(17):1375-1378

13. Yamabhai $M$, Emrat $S$, Sukasem $S$, Pesatcha $P$, Jaruseranee $N$, Buranabanyat B: Secretion of recombinant Bacillus hydrolytic enzymes using Escherichia coli expression systems. Journal of Biotechnology 2008, 133(1):50-57.

14. Henrissat B, Davies G: Structural and sequence-based classification of glycoside hydrolases. Curr Opin Struct Biol 1997, 7(5):637-644.

15. Coutinho PM, Henrissat B, (eds.): Carbohydrate-active enzymes: an integrated database approach. Cambridge: The Royal Societyof Chemistry; 1999.

16. Yan X-X, An X-M, Gui L-L, Liang D-C: From Structure to Function: Insights into the Catalytic Substrate Specificity and Thermostability Displayed by Bacillus subtilis Mannanase BCman. Journal of Molecular Biology 2008, 379(3):535-544.

17. Kunst F, Ogasawara N, Moszer I, Albertini AM, Alloni G, Azevedo V, Bertero $M G$, Bessieres $P$, Bolotin A, Borchert $S$, et al:: The complete genome sequence of the gram-positive bacterium Bacillus subtilis. Nature 1997, 390(6657):249-256.

18. Kremnicky L, Slavikova E, Mislovicova D, Biely P: Production of extracellular beta-mannanases by yeasts and yeast-like microorganisms. Folia Microbiol (Praha) 1996, 41(1):43-47.

19. He X, Liu N, Li W, Zhang Z, Zhang B, Ma Y: Inducible and constitutive expression of a novel thermostable alkaline $\beta$-mannanase from alkaliphilic Bacillus sp. N16-5 in Pichia pastoris and characterization of the recombinant enzyme. Enzyme and Microbial Technology 2008, 43(1):13-18.

20. Li YN, Meng K, Wang YR, Yao B: A beta-mannanase from Bacillus subtilis B36: purification, properties, sequencing, gene cloning and expression in Escherichia coli. Z Naturforsch [C] 2006, 61(11-12):840-846.

21. Mendoza NS, Arai M, Sugimoto K, Ueda M, Kawaguchi T, Joson LM Cloning and sequencing of beta-mannanase gene from Bacillus subtilis NM-39. Biochim Biophys Acta 1995, 1243(3):552-554.

22. Yoon KH, Chung S, Lim BL: Characterization of the Bacillus subtilis WL-3 mannanase from a recombinant Escherichia coli. J Microbiol (Seoul, Korea) 2008, 46(3):344-349.

23. Zhang $Q$, Yan $X$, Zhang L, Tang W: [Cloning, sequence analysis and heterologous expression of a beta-mannanase gene from Bacillus subtilis Z-2]. Mol Biol (Mosk) 2006, 40(3):418-424.

24. Ethier $N$, Talbot $G$, Sygusch J: Gene cloning, DNA sequencing, and expression of thermostable beta-mannanase from Bacillus stearothermophilus. Appl Environ Microbiol 1998, 64(11):4428-4432.

25. Li Y, Yang P, Meng K, Wang Y, Luo H, Wu N, Fan Y, Yao B: Gene cloning, expression, and characterization of a novel beta-mannanase from Bacillus circulans CGMCC 1416. J Microbiol Biotechnol 2008, 18(1):160-166

26. Davies $G$, Henrissat B: Structures and mechanisms of glycosyl hydrolases. Structure 1995, 3(9):853-859
27. Simmons LC, Yansura DG: Translational level is a critical factor for the secretion of heterologous proteins in Escherichia coli. Nat Biotechnol 1996, 14(5):629-634.

28. Do BC, Dang TT, Berrin JG, Haltrich D, To KA, Sigoillot JC, Yamabhai M: Cloning, expression in Pichia pastoris, and characterization of a thermostable GH5 mannan endo-1,4-beta-mannosidase from Aspergillus niger BK01. Microb Cell Fact 2009, 8:59.

29. Jiang Z, Wei Y, Li D, Li L, Chai P, Kusakabe I: High-level production, purification and characterization of a thermostable $\beta$-mannanase from the newly isolated Bacillus subtilis WY34. Carbohydrate Polymers 2006, 66(1):88-96.

30. Duffaud GD, McCutchen CM, Leduc P, Parker KN, Kelly RM: Purification and characterization of extremely thermostable beta-mannanase, beta-mannosidase, and alpha-galactosidase from the hyperthermophilic eubacterium Thermotoga neapolitana 5068. Appl Environ Microbiol 1997, 63(1):169-177.

31. Politz O, Krah M, Thomsen KK, Borriss R: A highly thermostable endo(1,4)-beta-mannanase from the marine bacterium Rhodothermus marinus. App/ Microbiol Biotechnol 2000, 53(6):715-721.

32. Rastall RA, Maitin V: Prebiotics and synbiotics: towards the next generation. Curr Opin Biotechnol 2002, 13(5):490-496.

33. Laemmli UK: Cleavage of structural proteins during the assembly of the head of bacteriophage T4. Nature 1970, 227(5259):680-685.

34. Bradford MM: A rapid and sensitive method for the quantitation of microgram quantities of protein utilizing the principle of protein-dye binding. Anal Biochem 1976, 72:248-254.

35. Miller GL: Use of Dinitrosalicylic Acid Reagent for Determination of Reducing Sugar. Analytical Chemistry 1959, 31(3):426-428.

36. Larkin MA, Blackshields G, Brown NP, Chenna R, McGettigan PA, McWilliam H, Valentin F, Wallace IM, Wilm A, Lopez R, et al:: Clustal W and Clustal X version 2.0. Bioinformatics 2007, 23(21):2947-2948.

37. Gouet P, Courcelle E, Stuart DI, Metoz F: ESPript: analysis of multiple sequence alignments in PostScript. Bioinformatics 1999, 15(4):305-308.

38. Setati ME, Ademark P, van Zyl WH, Hahn-Hagerdal B, Stålbrand H: Expression of the Aspergillus aculeatus endo-beta-1,4-mannanase encoding gene (man1) in Saccharomyces cerevisiae and characterization of the recombinant enzyme. Protein Expr Purif 2001, 21(1):105-114.

39. Puchart V, Vrsanská M, Svoboda P, Pohl J, Ögel ZB, Biely P: Purification and characterization of two forms of endo- $\beta$-1,4-mannanase from a thermotolerant fungus, Aspergillus fumigatus IMI 385708 (formerly Thermomyces lanuginosus IMI 158749). Biochimica et Biophysica Acta (BBA) - General Subjects 2004, 1674(3):239-250.

40. Ademark P, Varga A, Medve J, Harjunpaa V, Torbjorn D, Tjerneld F, Stålbrand $\mathrm{H}$ : Softwood hemicellulose-degrading enzymes from Aspergillus niger : Purification and properties of a $\beta$-mannanase. Journal of Biotechnology 1998, 63(3):199-210.

41. Chen X, Cao Y, Ding Y, Lu W, Li D: Cloning, functional expression and characterization of Aspergillus sulphureus beta-mannanase in Pichia pastoris. J Biotechnol 2007, 128(3):452-461.

42. Chen X, Lu W, Cao Y, Li D: Prokaryotic Expression, Purification and Characterization of Aspergillus sulphureus beta-Mannanase and SiteDirected Mutagenesis of the Catalytic Residues. Appl Biochem Biotechnol 2008, 149(2):139-144.

43. Talbot G, Sygusch J: Purification and characterization of thermostable beta-mannanase and alpha-galactosidase from Bacillus stearothermophilus. Appl Environ Microbiol 1990, 56(11):3505-3510.

44. Luthi E, Jasmat NB, Grayling RA, Love DR, Bergquist PL: Cloning, sequence analysis, and expression in Escherichia coli of a gene coding for a betamannanase from the extremely thermophilic bacterium "Caldocellum saccharolyticum". Appl Environ Microbiol 1991, 57(3):694-700.

45. Xu B, Hägglund P, Stålbrand H, Janson J-C: endo- $\beta-1,4-M a n n a n a s e s$ from blue mussel, Mytilus edulis : purification, characterization, and mode of action. Journal of Biotechnology 2002, 92(3):267-277.

46. Xu B, Sellos D, Janson JC: Cloning and expression in Pichia pastoris of a blue mussel (Mytilus edulis) beta-mannanase gene. Eur J Biochem 2002, 269(6):1753-1760.

47. Stålbrand H, Saloheimo A, Vehmaanpera J, Henrissat B, Penttila M: Cloning and expression in Saccharomyces cerevisiae of a Trichoderma reesei beta-mannanase gene containing a cellulose binding domain. Appl Environ Microbiol 1995, 61(3):1090-1097. 
48. Stålbrand H, Siika-aho M, Tenkanen M, Viikari L: Purification and characterization of two $\beta$-mannanases from Trichoderma reesei. Journal of Biotechnology 1993, 29(3):229-242.

49. Wei YH, Mao AJ, He YZ, Qiao Y, Dong ZY: [Expression of endo-betamannanase gene from Trichoderma reesei in Pichia pastoris]. Sheng Wu Gong Cheng Xue Bao 2005, 21(6):878-883.

50. Tamaku Y, Akaki T, Morishita T, Kimura T, Sakka K, Ohmiya K: Cloning, DNA sequencing, and expression of the $\beta$-1,4-mannanase gene from a marine bacterium, Vibrio sp. strain MA-138. Journal of Fermentation and Bioengineering 1997, 83(2):201-205.

doi: $10.1186 / 1475-2859-9-20$

Cite this article as: Songsiriritthigul et al., Efficient recombinant expression and secretion of a thermostable GH26 mannan endo-1,4-?-mannosidase from Bacillus licheniformis in Escherichia coli Microbial Cell Factories 2010, 9:20

Submit your next manuscript to BioMed Central and take full advantage of:

- Convenient online submission

- Thorough peer review

- No space constraints or color figure charges

- Immediate publication on acceptance

- Inclusion in PubMed, CAS, Scopus and Google Scholar

- Research which is freely available for redistribution

Submit your manuscript at www.biomedcentral.com/submit 